\title{
Exchangeable Basic Cations and Nitrogen Distribution in Soil as Affected by Crop Residues and Nitrogen
}

\author{
Ciro Antonio Rosolem* \\ Departamento de Produção Vegetal; Faculdade de Ciências Agronômicas de Botucatu; Universidade Estadual \\ Paulista Júlio de Mesquita Filho; C.P. 237; 18603-970; Botucatu - SP - Brasil
}

\begin{abstract}
In this work, a greenhouse experiment was conducted to study the effects of $N$ fertilization and residues of pearl millet, black oats and oilseed radish on $\mathrm{pH}$ and $\mathrm{Ca}, \mathrm{Mg}, \mathrm{K}, \mathrm{NO}_{3}^{-}$, and $\mathrm{NH}_{4}^{+}$distribution within the profile of a Distroferric Red Latosol. The equivalent of $8 \mathrm{t} \mathrm{ha} \mathrm{a}^{-1}$ of plant residues were placed on soil surface. Lime was applied on the soil surface and nitrogen was applied over the straw at 0, 50, 100, and $150 \mathrm{mg} \mathrm{kg}^{-1}$, as ammonium nitrate. Corn was grown for 57 days. Calcium contents and $\mathrm{pH}$ in the soil profile were decreased by Pearl millet residue, while black oat and oilseed radish increased Ca contents and these effects are not related with Ca contents in residue tissue. However, the presence of plant residues increased nitrate, ammonium, and potassium contents in the deeper layers of the pots.
\end{abstract}

Key words: Calcium, magnesium, nitrogen, potassium, soil bases, no till

\section{INTRODUCTION}

Considering the accumulated knowledge on liming in conventional cropping systems, it would be expected that surface liming in no-till would not ameliorate soil profile so as to avoid the plant growth and yield restrictions in acidic soils (Rosolem et al., 2004). Nevertheless, this has not been the case as reported in many studies (Pöttker and Ben, 1998; Caires et al., 1998, 1999). When lime is applied on soil surface in no-till systems, there has been formation of an alkalinizing front that slowly advances through the soil profile, neutralizing subsurface acidity (Caires et al., 1998; Amaral et al., 1998). Another possible base leaching mechanism under no-till is the formation of water-soluble organic complexes (Ziglio et al., 1999). In other words, on surface soil layers, organic ligands of low molecular weight resulting from plant residue decomposition (Aoyama 1996a, b) can complex the soil exchangeable bases, facilitating their mobility in soil. When the ion calcium, complexed with organic ligands, reaches subsurface layers, it can be displaced by the exchangeable aluminum, since $\mathrm{Al}^{3+}$ ions form more stable complexes with organic acids than $\mathrm{Ca}^{2+}$. Consequently, this process may cause a decrease in exchangeable acidity, and thus, increase exchangeable calcium in this soil layer. For magnesium, reactions would be similar. Potassium would accumulate in surface layers, since organic acids have less affinity with lowcharged cations (Rosolem et al., 2004). Franchini et al. (2001) observed that the effect of plant residues on lime mobility in soil varied with plant species, especially due to differences in their

*Author for correspondence: rosolem @ fca.unesp.br 
chemical composition. Furthermore, the magnitude of alterations on acidic soils chemistry when incubated with plant residues is determined by the total content of cations and carbon in the water-soluble fraction of plant residues (Franchini et al., 1999).

Although it is acknowledged that plant residues play an important role on basic cation mobilization in the soil, especially calcium, it is interesting to point out that $\mathrm{NO}_{3}{ }^{-}$ions are released during plant residue decomposition, as well as from fertilizers. Besides $\mathrm{SO}_{4}{ }^{2-}$ and $\mathrm{Cl}^{-}, \mathrm{NO}_{3}{ }^{-}$may also be paired with $\mathrm{Ca}^{2+}, \mathrm{Mg}^{2+}, \mathrm{K}^{+}$and $\mathrm{NH} 4+$ and contribute towards the mobilization of bases in the soil profile (Pearson et al., 1962; Caires et al., 1998; Amaral et al, 1998).

According to Shainberg et al. (1989), the most important companion-ion causing calcium to move downwards soil profile is sulfate. However, in some cases, an increase in $\mathrm{Ca}^{2+}$ but not in $\mathrm{SO}_{4}{ }^{2-}$ was observed in depth after $\mathrm{CaSO}_{4}$ was applied on the surface (Silva et al., 1998). Caires et al. (1998) also observed that $\mathrm{Ca}^{2+}$ and $\mathrm{SO}_{4}{ }^{2-}$ gradients in the soil profile were different, so that $\mathrm{S}-\mathrm{SO}_{4}{ }^{2-}$ moved more rapidly than $\mathrm{Ca}^{2+}$. Considering this divergence between calcium and sulfate accumulation patterns in soil profile when gypsum was applied Farina and Channon (1988) proposed that nitrate could be the Ca companion-ion during the descending movement. Nitrate is very mobile in the profile, since the energy with which it is adsorbed to soil particles is very low. In no-till systems, such mobility is even higher, as less water evaporates from the surface; consequently, nitrates tend to follow the water flow into deeper soil layers (Bortolini et al., 2000).

Lime effect was observed down to a depth of 61 $\mathrm{cm}$ when large amounts of lime and nitrogen fertilizers were applied on soil surface (Pearson et al., 1962). However, base leaching was not expressive when $\mathrm{NO}_{3}{ }^{-}$was not applied. This result was attributed to the reaction between nitrogen from the fertilizer and ions from lime dissociation $(\mathrm{Ca}$ and $\mathrm{Mg}$ ), forming soluble salts that were subject to leaching. Caires et al. (1999) observed that surface liming increased the exchangeable $\mathrm{Ca}$ in the subsoil $(60-80 \mathrm{~cm})$, probably because soil samplings on the interrows of a corn field were performed after the application of $\mathrm{N}$ as sidedressing, indicating the occurrence of calcium leaching accompanied by nitrate.

This work studied the effect of black oat, pearl millet, and oilseed radish residues left on soil surface, in association with nitrogen fertilizer rates on $\mathrm{pH}$, basic cations and inorganic nitrogen distribution in the soil profile.

\section{MATERIALS AND METHODS}

A greenhouse experiment was conducted using $40 \mathrm{~cm}$-tall, $15 \mathrm{~cm}$-diameter PVC tubes. The soil used in the experiment was collected from the plough layer of a Typic Hapludox (Dystroferric Red Latosol, according to Embrapa, 1999) with $690 \mathrm{~g} \mathrm{~kg}^{-1}$ sand, $160 \mathrm{~g} \mathrm{~kg}^{-1}$ clay, and $150 \mathrm{~g} \mathrm{~kg}^{-1}$ silt. Soil chemical analysis (Raij et al., 2001) showed $\mathrm{pH}(\mathrm{CaCl} 2) 4.1,1.8 \mathrm{~g} \mathrm{dm}^{-3}$ of organic matter, $1.0 \mathrm{mg} \mathrm{dm}^{-3} \mathrm{P}$ (resin), 75, 0.1, 4.0, and 1.0 $\mathrm{mmol}_{\mathrm{c}} \mathrm{dm}^{-3}$ of $\mathrm{H}+\mathrm{Al}, \mathrm{K}, \mathrm{Ca}$, and $\mathrm{Mg}$, respectively, and $7 \%$ base saturation.

Pots were made using PVC tubes sectioned in rings that were mounted one on top of the other, corresponding to four depths $(0-5,5-10,10-20$, and $20-40 \mathrm{~cm}$ ), which were filled with soil at the same bulk density as in the field. An additional ring $(2.5 \mathrm{~cm})$ was added to the upper part of each pot to accommodate the plant residues on soil surface. Soil losses through the bottom of the pots was prevented by attaching a nylon net. Potassium was added at $150 \mathrm{mg} \mathrm{dm}^{-3}$ as potassium chloride and $\mathrm{P}$, as superphosphate, was applied at $150 \mathrm{mg}$ $\mathrm{dm}^{-3}$, mixed to the soil before filling the tubes. Soil water content was monitored daily by weighing the pots in the afternoon. Every time when the water retention capacity reached $60 \%$, surface irrigation was used to raise it to $100 \%$. There was some solution loss through the bottom of the pots, but it was not monitored.

The treatments consisted of four soil cover crop species, i.e., black oat (Avena strigosa), pearl millet (Pennisetum glaucum), oilseed radish (Rhaphanus Sativus), and no residues, combined with four nitrogen rates applied as ammonium nitrate $\left(0,50,100\right.$, and $\left.150 \mathrm{mg} \mathrm{dm}^{-3}\right)$. Black oat, pearl millet and oilseed radish were collected in the field at full bloom. The plants were chopped in particles approximately $3.0 \mathrm{~cm}$ long while still green and placed in an oven at $60^{\circ} \mathrm{C}$ for $60 \mathrm{~h}$. Upon drying, one sample from each material was collected, ground, and analyzed for $\mathrm{C}, \mathrm{N}, \mathrm{P}, \mathrm{K}, \mathrm{Ca}$, $\mathrm{Mg}$, and $\mathrm{S}$ contents (Table 1) as in Malavolta et al. (1997). Plant residues were placed on soil surface in amounts equivalent to $8 \mathrm{t} \mathrm{ha}^{-1}$ of dry matter. Next, dolomitic lime $\left(228 \mathrm{~g} \mathrm{~kg}^{-1} \mathrm{CaO}\right.$ and $109 \mathrm{~g}$ $\mathrm{kg}^{-1} \mathrm{MgO}$ ) was applied over the straws at a rate 
equivalent to $5.67 \mathrm{t} \mathrm{ha}^{-1}$, calculated to increase soil base saturation to $70 \%$. One week later, by the time corn was planted, nitrogen was applied over the plant residues at rates of $0,50,100$, and 150 $\mathrm{mg} \mathrm{dm}{ }^{-3}$.

One corn plant (single hybrid, Braskalb XL-251) was grown per pot. Thirty days after the plant emergence, $50 \mathrm{mg} \mathrm{dm}^{-3} \mathrm{P}, 60 \mathrm{mg} \mathrm{dm}^{-3} \mathrm{~K}$, and 3 $\mathrm{mg} \mathrm{dm}{ }^{-3} \mathrm{Zn}$ were applied in solution in order to correct the deficiency symptoms. Fifty seven days after the emergence, pots were disassembled according to ring thickness, and samples were analyzed for $\mathrm{pH}, \mathrm{Ca}, \mathrm{Mg}, \mathrm{K}$, and inorganic $\mathrm{N}$ contents as in Raij et al. (2001).

The experimental design was a $4 \times 4$ factorial with six replicates. ANOVA was run and the results were compared in each soil depth using LSD. Regressions were fit for dry matter yield.

Table 1 - Macronutrients and carbon contents on plant residues at the beginning of the experiment.

\begin{tabular}{|c|c|c|c|c|c|c|c|c|}
\hline Straw & $\mathbf{N}$ & $\mathbf{P}$ & $\mathbf{K}$ & $\mathbf{C a}$ & $\mathrm{Mg}$ & $\mathbf{S}$ & $\mathrm{C}$ & $\mathbf{C} / \mathbf{N}$ \\
\hline & & & & $\mathrm{kg}^{-1}$ & & & & \\
\hline Black oat & 16.4 & 0.39 & 16.5 & 6.7 & 2.6 & 1.8 & 429 & 35 \\
\hline Pearl millet & 12.2 & 0.40 & 7.5 & 6.2 & 3.6 & 1.8 & 405 & 25 \\
\hline Oilseed radish & 23.2 & 1.12 & 13.1 & 24.2 & 8.0 & 2.1 & 372 & 16 \\
\hline
\end{tabular}

\section{RESULTS}

A summary of the analysis of variance for $\mathrm{pH}$, soil exchangeable bases, and nitrogen at depths of 0-5, 5-10, 10-20, and 20-40 cm is presented in Table 2. Lime effect on soil $\mathrm{pH}$ was generally confined to the uppermost soil layer (Figure 1). Nitrogen rates had no significant effect on $\mathrm{pH}$ under black oat and in the treatment without residues, but under pearl millet residues, $\mathrm{pH}$ values decreased as nitrogen rates increased (Figure 1).

Table 2 - Analysis of variance for $\mathrm{pH}$ values and $\mathrm{K}, \mathrm{Ca}$, and $\mathrm{Mg}$ contents in the $0-5,5-10,10-20$, and 20-40cm soil layers due to straw type and nitrogen fertilization.

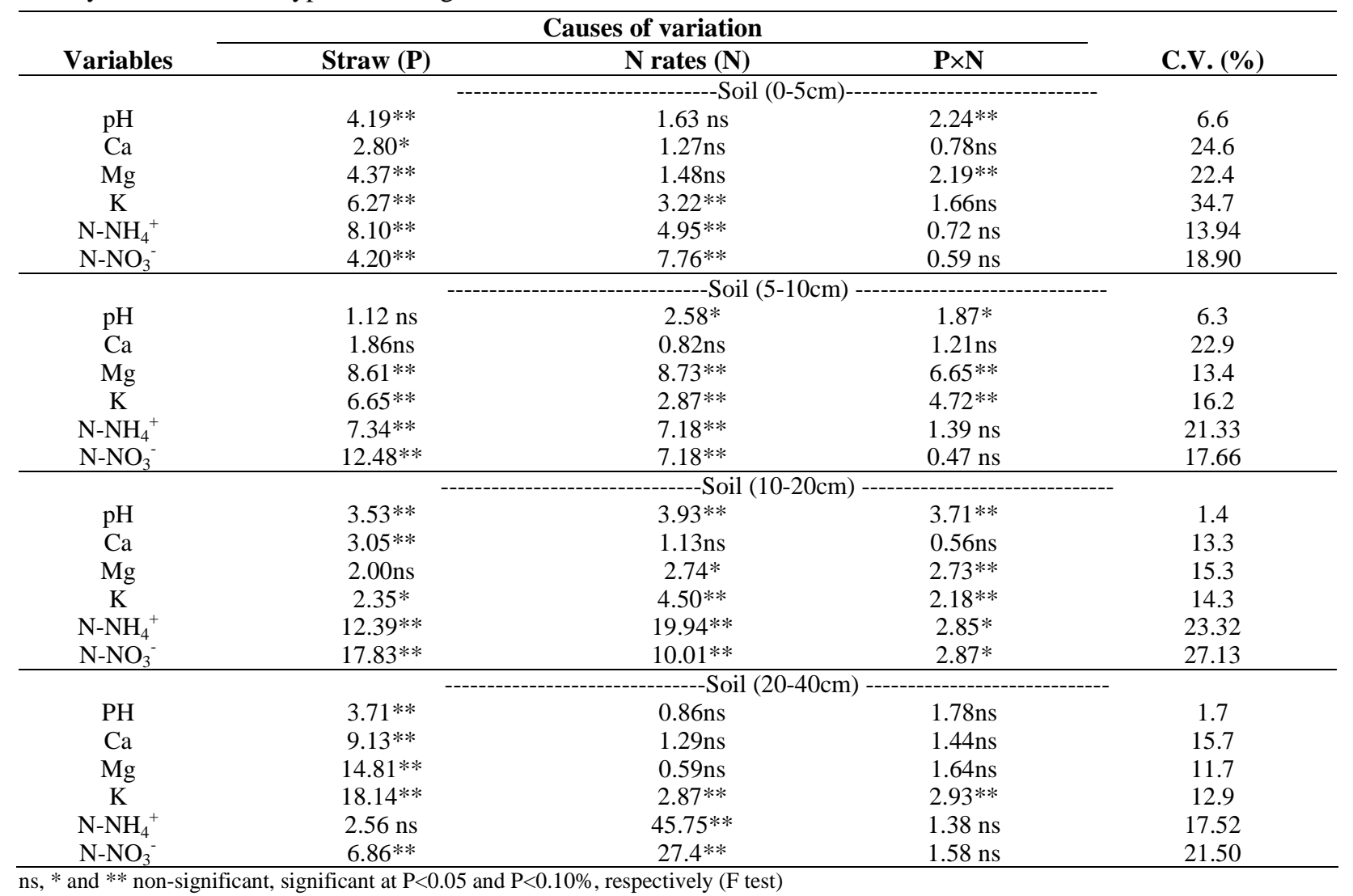



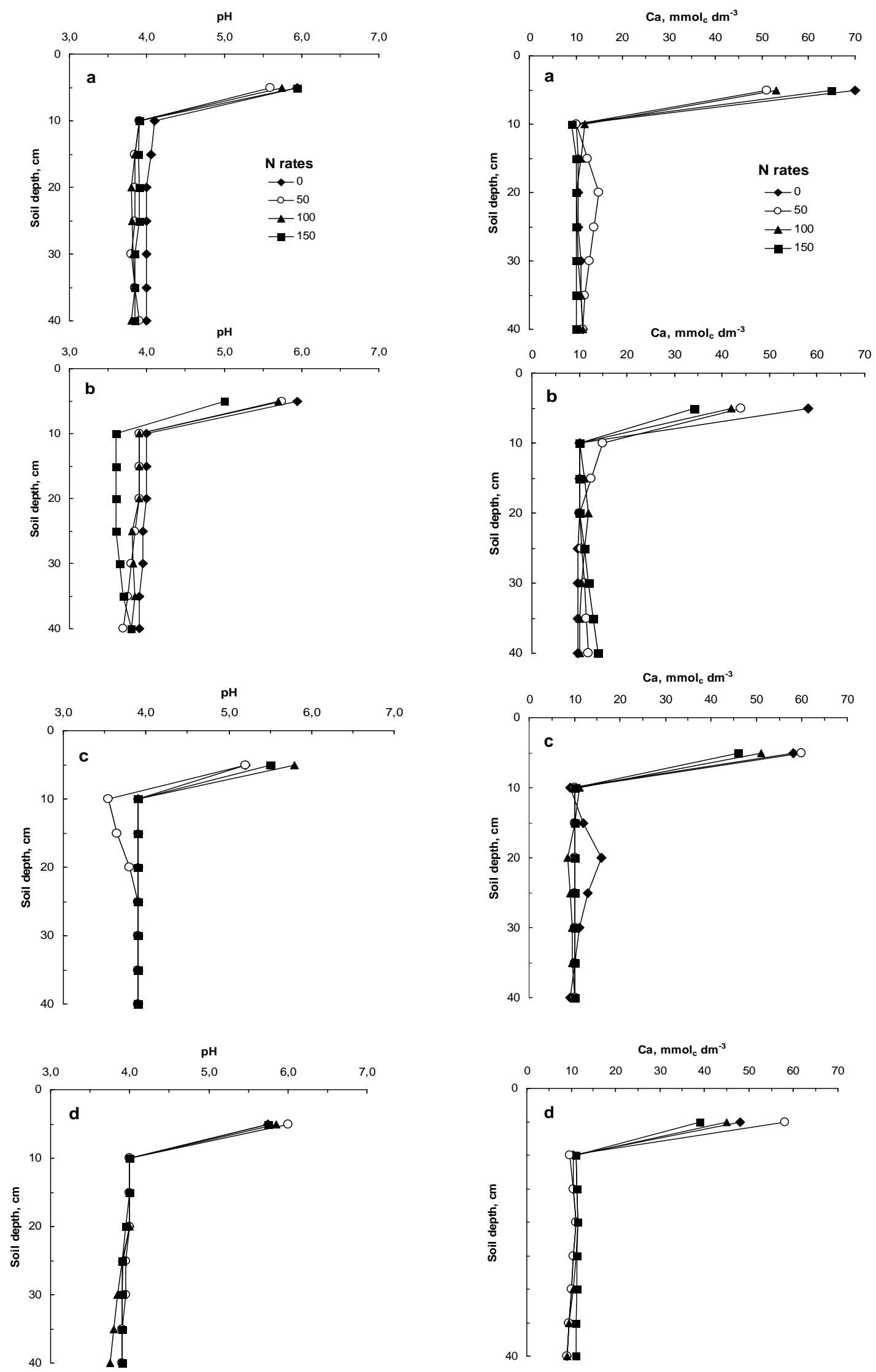

Figure 1 - $\mathrm{pH}$ values and $\mathrm{Ca}$ contents in the soil profile as affected by nitrogen application onto various straw mulches. a. Black oat; b. Pearl millet; c. Oilseed radish; d. No straw. 
Results observed for oilseed radish were inconclusive. The presence of black oat and oilseed radish residues generally resulted in higher exchangeable $\mathrm{Ca}$ contents in the soil, mainly on the surface; the opposite was observed for millet (Figure 1 and Table 2). For oilseed radish, this probably occurred due to the high concentration of calcium in dry matter; therefore, soil calcium contents on surface layer might have resulted from straw washing. But this was not true for black oat. Franquini et al. (1999) also found high calcium contents in oilseed radish.

For soil $\mathrm{Mg}$, although the analysis of variance indicated significant differences for the straw $x$ nitrogen interaction in the $0-5,5-10$, and $10-20$ $\mathrm{cm}$ layers (Table 2), they have little biological significance (Figure 2). However, on average, black oat increased $\mathrm{Mg}$ contents in the soil surface layer. This was not expected since black oats showed the lower $\mathrm{Mg}$ contents in dry matter. There was a negative relation between $\mathrm{N}$ rates and $\mathrm{K}$ content in the $0-5 \mathrm{~cm}$ soil layer, except in the treatment without straw (Figure 2). In the absence of nitrogen fertilization, under both black oat and oilseed radish, there was more $\mathrm{K}$ in soil than for millet or the treatment without straw. It is interesting to observe that black oat and oilseed radish showed much higher amounts of tissue $\mathrm{K}$
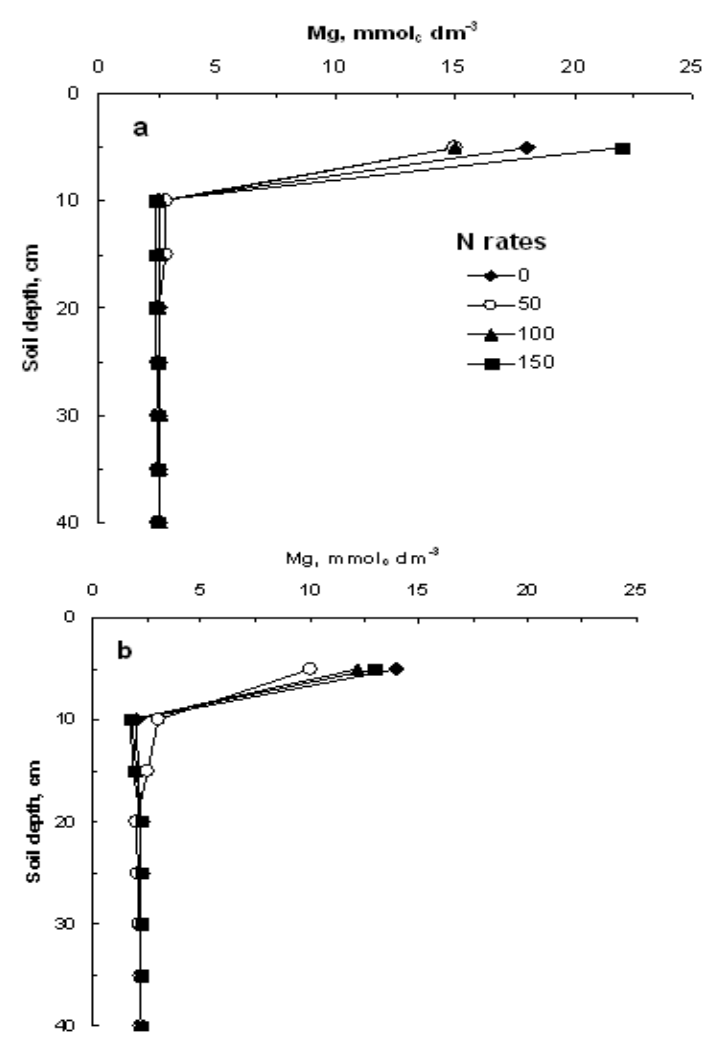

than millet (Table 1).

In the case of $\mathrm{N}^{-\mathrm{NH}_{4}}$ under black oat residues, on average there were smaller $\mathrm{N}-\mathrm{NH}_{4}{ }^{+}$contents in the soil profile, than under other types of straw (Figure $3)$. This result is an indication of greater nitrogen immobilization by the soil's microbial population, stimulated by a higher $\mathrm{C} / \mathrm{N}$ ratio in black oat residues. The $\mathrm{C} / \mathrm{N}$ ratio for black oat was 35 , while millet had a value of 25 , and oilseed radish had a value of 16 (Table 1 ).

On average, there were higher nitrate contents than ammonium contents in the uppermost soil layer $(0-5 \mathrm{~cm})$. An inversion occurred at deeper layers, with higher ammonium contents. This was probably caused by a greater activity of nitrifying microorganisms on the soil surface layer, as a result of greater aeration and the effects of surface liming on that layer, which had higher $\mathrm{pH}$. Residues on soil surface generally increased corn dry matter yields, but there was a positive response to nitrogen application, up to $85 \mathrm{mg} \mathrm{dm}^{-3}$, only for black oat residues (Figure 4). However, in the treatment without straw, the application of nitrogen caused a significant corn dry matter yield decrease. Such decrease in dry matter yield could be a consequence of decreased potassium absorption, since potassium was one of the most leached nutrients.
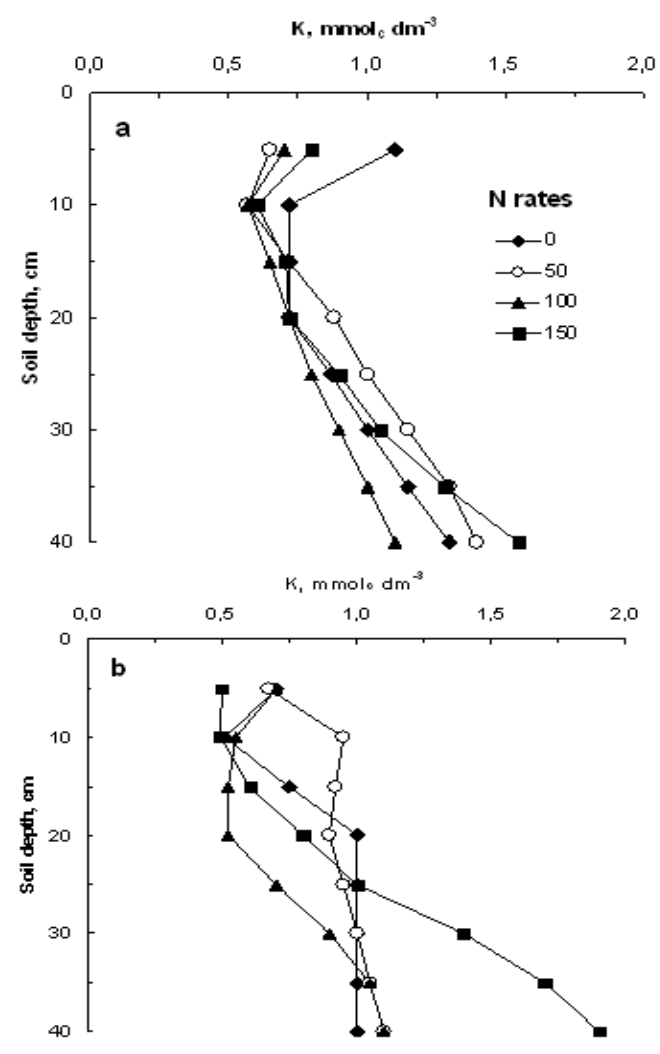

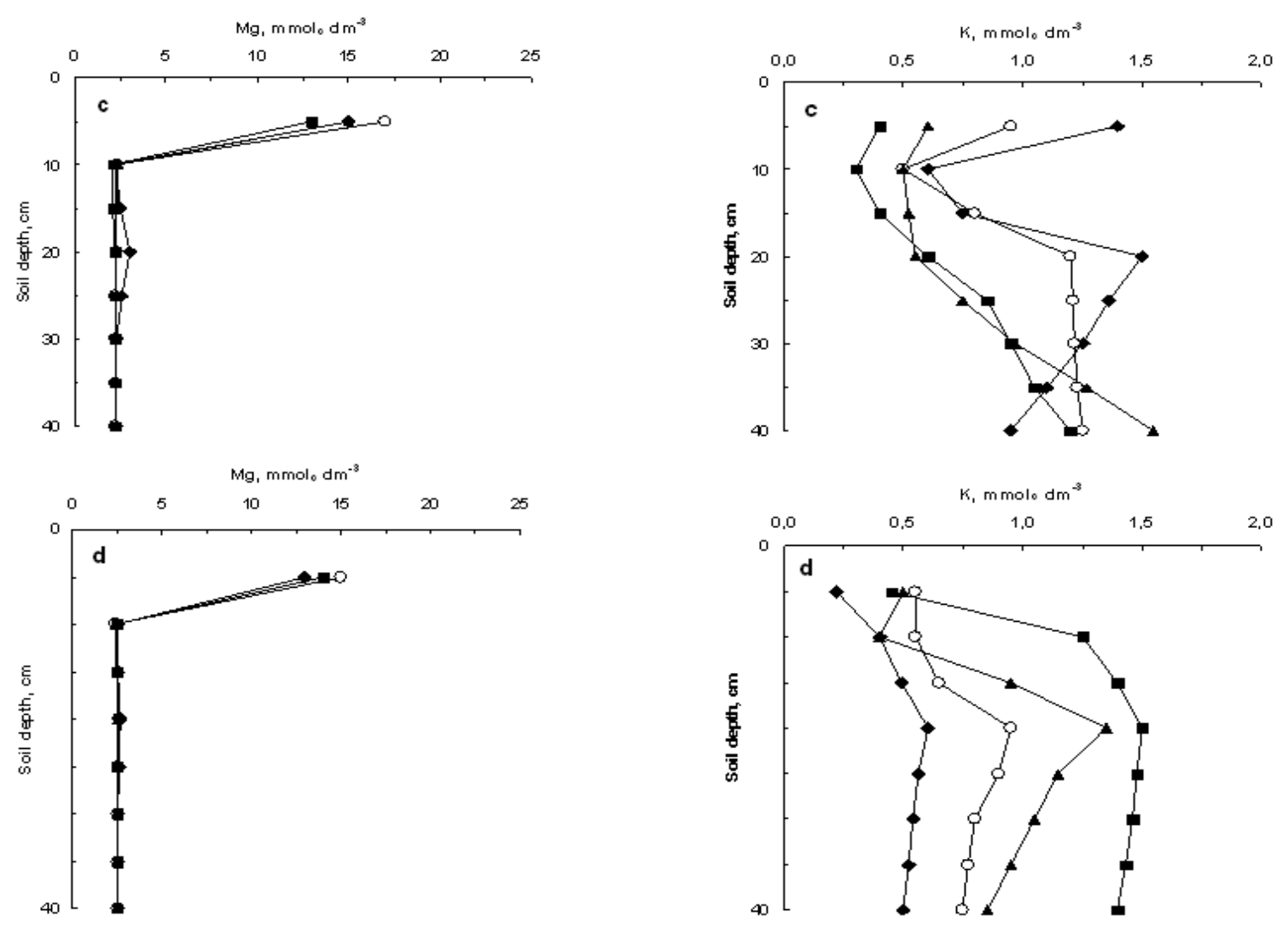

Figure 2 - $\mathrm{Mg}$ and $\mathrm{K}$ contents in the soil profile as affected by nitrogen application onto various straw mulches. a. Black oat; b. Pearl millet; c. Oilseed radish; d. No straw.
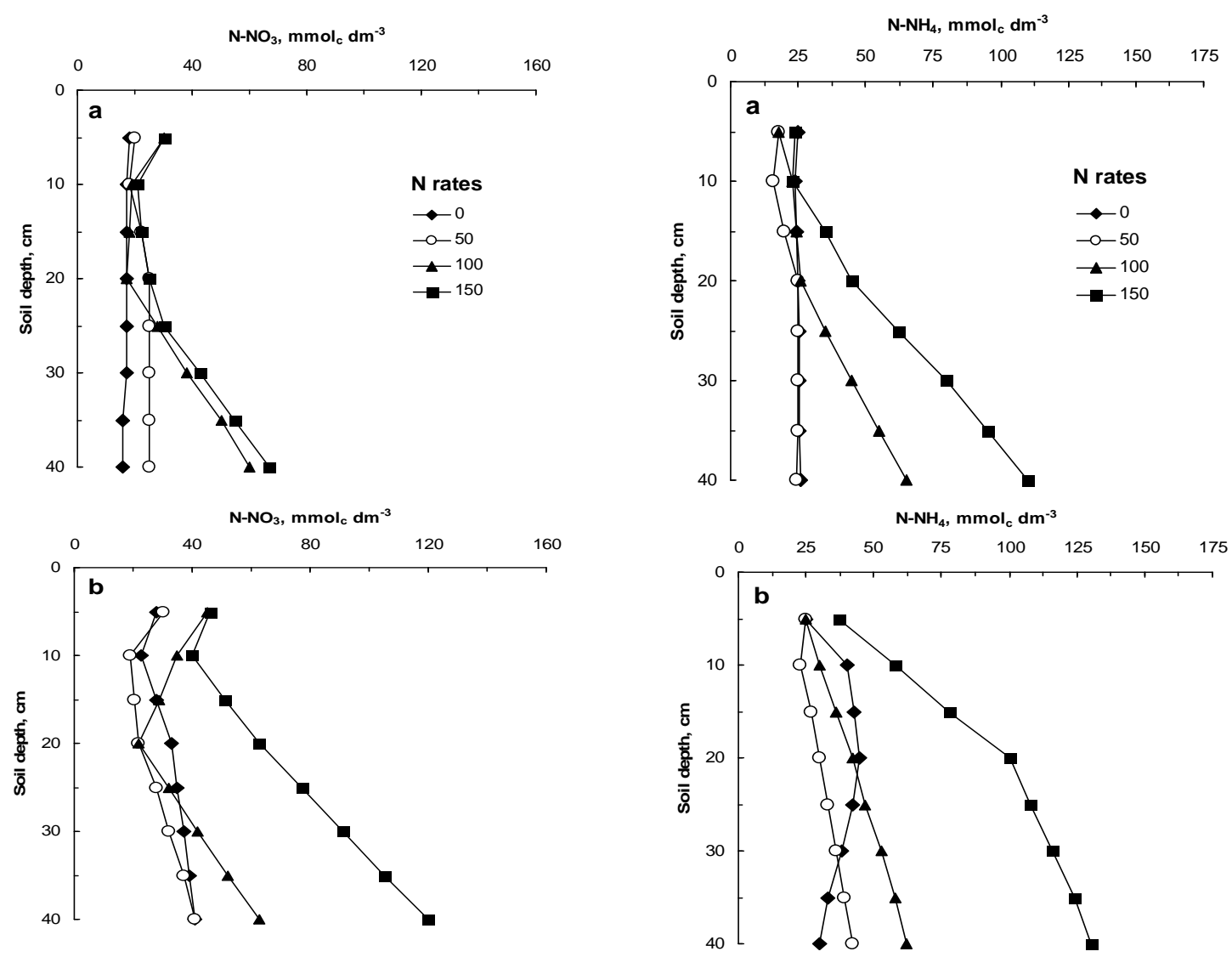

Braz. Arch. Biol. Technol. v.54 n.3: pp. 441-450, May/June 2011 

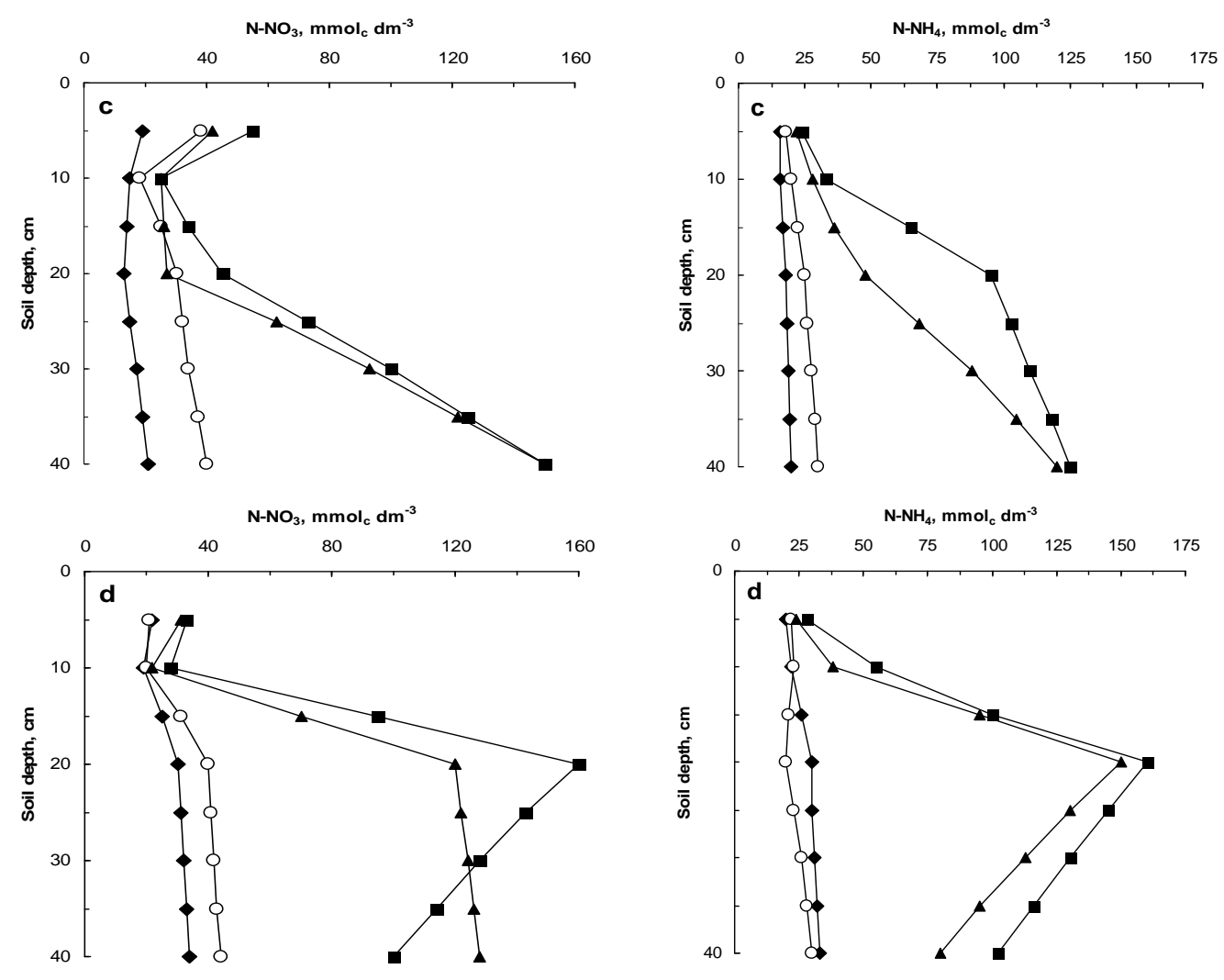

Figure $3-\mathrm{N}-\mathrm{NH}_{4}$ and $\mathrm{N}-\mathrm{NO}_{3}$ contents in the soil profile as affected by nitrogen application onto various straw mulches. a. Black oat; b. Pearl millet; c. Oilseed radish; d. No straw.

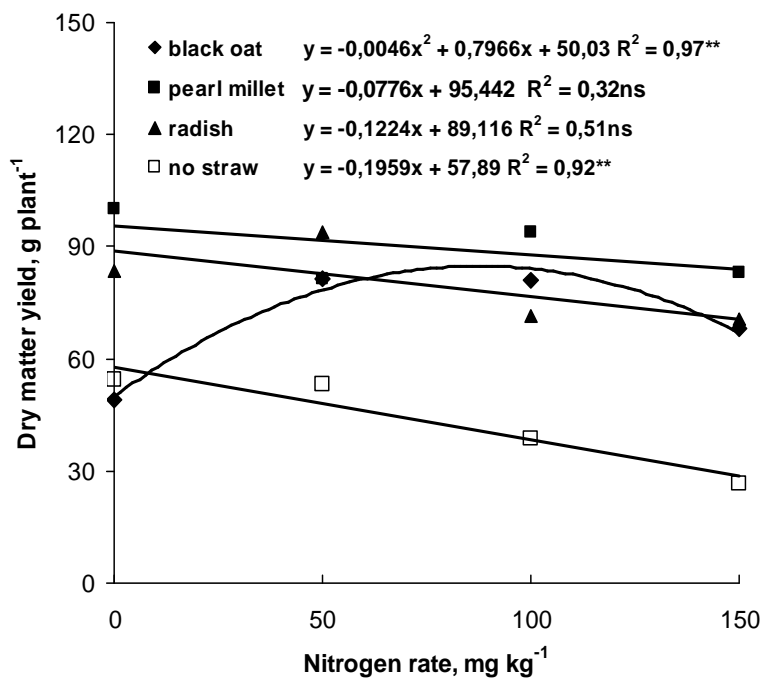

Figure 4 - Relative dry matter yield of corn plants harvested at 57 days after emergence, as affected by nitrogen rates and straw mulches. ** significant regression equation, ns.. nonsignificant regression equation $(\mathrm{P}<0.01, \mathrm{~F}$ test $)$. 


\section{DISCUSSION}

The fact that $\mathrm{pH}$ did not change when nitrogen fertilizer was applied over black oat and radish residues and also in the treatment without straw (Figure 1) suggests that, in such situations, the application of ammonium nitrate immediately after applying lime mighthave overcome the fertilizer acidifying effect. Another hypothesis would be that the very absorption of $\mathrm{NO}_{3}^{-}$by corn plants, generating $\mathrm{OH}^{-}$ions in the rhizosphere, would neutralize protons generated from the fertilizer.

Franquini et al. (1999) mixed plant residues with soil and observed positive effects of oilseed radish on soil acidity neutralization as compared to soybean and wheat, and attributed the fact to a higher hydrogen neutralization capacity of radish residues, which is not supported by the present results. But in the present experiment, the straw was left on soil surface.

Rosolem et al. (2003) also found no effect of $\mathrm{N}$ rates on soil $\mathrm{pH}$. Considering that $\mathrm{N}$ was applied on soil surface, nitrification must have been more intense in the uppermost soil layer, where $\mathrm{pH}$ was not modified by $\mathrm{N}$ rates. At first, liming must have increased the $\mathrm{pH}$ in this soil region that later decreased ammonium nitrification.

A higher exchangeable $\mathrm{Ca}$ contents in the soil (Figure 1 and Table 2) was related to $\mathrm{Ca}$ contents in plant residues only in the case of oilseed radish. Also, for $\mathrm{Mg}$, there was no relationship between the residues and soil contents. Hence, a cover crop with high $\mathrm{Ca}$ or $\mathrm{Mg}$ contents would not always result in higher soil $\mathrm{Ca}$ and/or $\mathrm{Mg}$ contents.

As a result of an intensified $\mathrm{K}$ leaching from the straw into the soil, a higher $\mathrm{K}$ content in the uppermost soil layer would be expected. This has been previously observed (Rosolem et al., 2003, 2005). The same was true for black oat and oilseed radisch that showed higher $\mathrm{K}$ tissue contents. A negative relation between $\mathrm{N}$ rates and $\mathrm{K}$ content in the $0-5 \mathrm{~cm}$ soil layer (Figure 2) could be understood considering that nitrification was favored by $\mathrm{N}$ applications and by $\mathrm{pH}$ values above 5.5 , supplying $\mathrm{NO}_{3}^{-3}$ that would then be leached and could be accompanied by $\mathrm{K}$. There was evidence of greater $\mathrm{K}$ leaching in the intermediate layers of the pots in treatments containing straw on the soil surface, contrary to what was expected, because there should be a greater affinity of organic acids for highly-charged cations (Miyazawa et al., 1992). The results found in this experiment do not support those obtained by several authors (Miyazawa et al., 1992; Caires et al., 1998) for calcium movement in depth as a response to surface liming. However, the conditions in each experiment might have been the cause of variation in results, since factors such as the amount of straw mulch and moisture could be relevant. One example of this is that the equivalent to $40 \mathrm{t}$ ha $^{-1}$ straw were used in the experiment of Franchini et al. (1999), while an amount equivalent to $8 \mathrm{t} \mathrm{ha}^{-1}$ was used in the present experiment, which was a condition closer to actual field conditions.

The effect of nitrogen fertilization on base movement through the soil profile is also arguable. Foloni and Rosolem (2006) observed greater leaching of bases with increased nitrogen fertilization. Nevertheless, the source of nitrogen used in their experiment was ammonium sulfate, while ammonium nitrate was used in the present experiment. Therefore, another important factor to be considered is the participation of the ion sulfate $\left(\mathrm{SO}_{4}{ }^{-2}\right)$ in calcium movement. Chaves et al. (1991) emphasized the greater affinity of the ion $\mathrm{Ca}^{2+}$ with sulfate than with nitrate.

The $\mathrm{C} / \mathrm{N}$ ratio has an important impact on $\mathrm{N}$ dynamic in the soil and plant residues used in this experiment had very different ratios (black oat $=$ 35 , millet $=25$, oilseed radish $=16$ ). The balance between nitrogen mineralization and immobilization by soil microorganisms is achieved at $\mathrm{C} / \mathrm{N}$ ratios between 20 and 30 , and in this case, greater releases of $\mathrm{N}^{-\mathrm{NH}_{4}}{ }^{+}$take place. The same was observed in the present work for millet and oilseed radish. However, when this ratio reaches the values higher than 30 , as in the case of black oat, immobilization exceeds mineralization, with lower release of $\mathrm{N}-\mathrm{NH}_{4}{ }^{+}$into the environment. The results observed in the present study for the effect of $\mathrm{C} / \mathrm{N}$ ratio on nitrogen mineralization are in agreement with those found by several authors (Bortolini et al., 2000; Aita et al., 2001; Heinrichs et al., 2001). Still, as expected, it could be observed that, regardless of the presence of residues of high $\mathrm{C} / \mathrm{N}$ ratio, highest nitrogen rates led to greater soil $\mathrm{N}-\mathrm{NH}_{4}{ }^{+}$contents, especially in the deeper soil layers $(20-40 \mathrm{~cm})$. However, in the treatment without straw, $\mathrm{N}-\mathrm{NH}_{4}{ }^{+}$contents were higher than in the presence of residues down to 10 $-20 \mathrm{~cm}$, but deeper leaching was not as severe as that observed in the presence of plant residues on the soil surface (Figure 3). This could be due to a better water conservation and infiltration under mulch. A similar trend was observed for soil N- 
$\mathrm{NO}_{3}{ }^{-}$(Figure 3). Leaching of $\mathrm{N}_{-} \mathrm{NO}_{3}{ }^{-}$in the soil profile was lower under black oat and higher under radish, but was not related with $\mathrm{N}$ contents in dry matter. Hence, there might have been an increase in nitrogen immobilization by microorganisms with black oat and pearl millet, due to the $\mathrm{C} / \mathrm{N}$ ratio values of these materials.

On the other hand, the greater nitrogen leaching at the higher nitrogen rates without the occurrence of Ca movement (Figure 1) confirmed that there was no connection between $\mathrm{Ca}$ movement through the soil profile and nitrogen fertilization, differing from Pearson et al. (1962) and Farina and Channon (1988).

\section{CONCLUSIONS}

Pearl millet residue decreased the $\mathrm{pH}$ and $\mathrm{Ca}$ contents in the soil profile, while black oat and oilseed radish increased $\mathrm{Ca}$ contents. These effects were not related with $\mathrm{Ca}$ contents in residue tissue. The presence of straw as well as increasing $\mathrm{N}$ rates intensified nitrate, ammonium, and potassium movement through the soil profile.

\section{ACKNOWLEDGMENTS}

This study was funded by CNPq (The National Council for Scientific and Technological Development) and FAPESP (The State of São Paulo Research Foundation).

\section{REFERENCES}

Aita, C., Basso, C.J., Ceretta, C.A., Gonçalves, C. N. and Da Ros, C.O. (2001). Plantas de cobertura de solo como fonte de nitrogênio ao milho. Rev. Bras. Ciênc. Solo, 25, 157-65.

Aoyama, M. (196a)) Fractionation of water-soluble organic substance formed during plant residue decomposition and high performance size exclusion chromatography of the fractions. Soil Sci. Plant Nutr., 42, 21-30.

Aoyama, M. (1996b). Use of high performance size exclusion chromatography to monitor the dynamics of water-soluble organic substances during the decomposition of plant residues in soil. Soil Sci. Plant Nutr., 42, 31-40.
Amaral, F.C.S., Vettorazzo, S.C. and Chitolina, J.C. (1998), Efeito do fluoreto de cálcio e do carbonato de cálcio na decomposição química da solução percolada de um solo ácido. Rev. Bras. Ciênc. Solo, 22,.397-85, 1998.

Bortolini, C.G., Silva, P.R.F. and Argenta, G. (2000), Sintomas consorciado de aveia preta e ervilha comum como cobertura de solos e seus efeitos na cobertura do milho em sucessão. Rev. Bras. Ciênc. Solo, 24, 897-903.

Caires, E.F., Chueiri, W.A., Madruga, E.F. and Figueiredo, A. (1998), Alterações de características químicas do solo e resposta da soja ao calcário e gesso aplicados na superfície em sistema de cultivo sem preparo do solo. Rev. Bras. Ciênc. Solo, 22, $27-$ 34.

Caires, E.F., Fonseca, A.F., Mendes, J., ChueirI, W.A. and Madruga, E.F. (1999), Produção de milho, trigo e soja em função das alterações das características químicas do solo pela aplicação de calcário e gesso na superfície, em sistema de plantio direto. Rev. Bras. Ciênc. Solo, 23, 315-27.

Chaves, J.C.D., Pavan, M.A. and Miyazawa, M. (1991), Especiação química da solução do solo para interpretação da absorção de cálcio e alumínio por raízes de cafeeiro. Pesqui. Agropecu. Bras., 26, 44757.

Embrapa. Centro Nacional de Pesquisa de Solos. (1999), Sistema brasileiro de classificação de solos. Brasília, Embrapa Produção de Informação. 412p

Farina, M.P.W. and Channon, P. (1998), Acid-subsoil amelioration. II Gypsium effects on growth and subsoil chemical properties. Soil Sci. Soc. Am. J., 52, 175-180.

Foloni, J.S.S. and Rosolem, C.A. (2006) Efeito da calagem e sulfato de amônio no algodão. I Transporte de cátions ânions no Solo. Rev. Bras. Ciência do Solo, 30, 425-432.

Franchini, J.C., Malavolta, E., Miyazawa, M. and Pavan, M.A. (1999), Alterações químicas em solos ácidos após a aplicação de resíduos vegetais. Rev. Bras. Ciênc. Solo, 23, 533-42.

Franchini, J.C., Meda, A.R., Cassilato, M.E., Miyazawa, M. and Pavan, M. (2001) Potencial de extratos de resíduos vegetais na mobilização do calcário no solo por métodos biológicos. Sci. Agric., 58, 357-60.

Heinrichs, R., Aita, C., Amado, T.J.C. and Fancelli, A.L. (2001), Cultivo consorciado de aveia e ervilha: relação $\mathrm{C} / \mathrm{N}$ da fitomassa e produtividade do milho em sucessão. Rev. Bras. Ciênc. Solo, 25, 331-40.

Malavolta, E., Vitti, G.C. and Oliveira, S.A. (1997) Avaliação do estado nutricional das plantas. Piracicaba, Potafos, 319p. 
Miyazawa, M., Chierice, G.O. and Pavan, M.A. (1992), Amenização de toxidez de alumínio às raízes de trigo pela complexação de ácidos orgânicos. Rev. Bras. Ciênc. Solo, 16, .209-15.

Pearson, R.W., Abruna, F. and Vice-Chandler, J. (1962), Effect of lime and nitrogen application on downward movements of calcium and magnesium in two humid tropical soils of Puerto Rico. Soil Sci., 93, 77-82.

Pöttker, D. and Ben, J.R. (1998), Calagem para uma rotação de culturas em sistema plantio direto. Rev. Bras. Ciênc. Solo, 22, 675-84.

Raij, B. van, Andrade, J.C., Cantarella, H. and Quaggio, J.A. (2001), Análise química para avaliação da fertilidade de solos tropicais. Campinas, Instituto Agronômico de Campinas, 284p.

Rosolem, C.A., Calonego, J.C., Foloni, J.S.S. (2003), Lixiviação de potássio da palha de coberturas de solo em função da quantidade de chuva recebida. Revista Brasileira de Ciência do Solo, 27, 355-362.
Rosolem, C. A.; Calonego, J. C. and Foloni; J.S.S. (2005), Potassium leaching from millet straw as affected by rainfall and potassium rates. Communications in Soil Science and Plant Analysis, 36, 1063-1074.

Shainberg, I., Sumner, M.E., Miller, W.P., Farina, M.P.W. and Fey, M.V. (1989), Use of gypsum on soils: a review. Adv. Soil Sci., 9, 1-111.

Ziglio, C.; Miyazawa, M.; Pavan, M.A. (1999), Formas orgânicas e inorgânicas de mobilização do cálcio no solo. Braz. Arch. Biol. Technol., 42, 257-26299.

Received: January 27, 2010; Revised: November 26, 2010; Accepted: March 31, 2011. 